\title{
Water depth selection during foraging and efficiency in prey capture by the egrets Casmerodius albus and Egretta thula (Aves, Ardeidae) in an urban lagoon in Rio de Janeiro State, Brazil
}

\author{
Aline B. Moreno ${ }^{1}$, Adriano R. Lagos ${ }^{2} \&$ Maria Alice S. Alves ${ }^{3}$
}

1. Programa de Iniciação Científica (PIBIC/CNPq), Departamento de Ecologia, Universidade do Estado do Rio de Janeiro (UERJ)

2. Programa Pós-Graduação em Ecologia, Universidade Federal do Rio de Janeiro.

3. Departamento de Ecologia, UERJ, São Francisco Xavier, 524, 20550-011 Rio de Janeiro, RJ, Brasil. (masa@uerj.br)

\begin{abstract}
This study aimed to evaluate the water depth selection during foraging, the efficiency in prey capture, and the food items captured by Casmerodius albus (Linnaeus, 1758) and Egretta thula (Molina, 1782). The work was conducted at an urban lagoon, Lagoa Rodrigo de Freitas, Rio de Janeiro. Four transects were made each month (two in the morning and two in the afternoon) for six months. When the birds were detected foraging, the water depth and the types of prey captured were recorded. There was no significant relationship between the foraging efficiencies of the two species. However, they differed in relation to the water depth when foraging, and also in the food items captured. Casmerodius albus captured mainly fishes while Egretta thula captured mainly invertebrates. The results suggest that the differences in water depth when foraging and the food items captured allow a differential use of the food resources available by $C$. albus and E. thula at Lagoa Rodrigo de Freitas.
\end{abstract}

KEYWORDS. Foraging depth, Casmerodius albus, Egretta thula, Lagoa Rodrigo de Freitas.

RESUMO. Seleção de profundidade da água durante o forrageamento e eficiência na captura de presas por Casmerodius albus e Egretta thula (Aves, Ardeidae) em uma lagoa urbana no Estado do Rio de Janeiro, Brasil. Este estudo teve o objetivo de avaliar a seleção de profundidade durante o forrageamento, a eficiência na captura de presas e os itens alimentares capturados por Casmerodius albus (Linnaeus, 1758) e Egretta thula (Molina, 1782). O trabalho foi realizado em uma lagoa urbana, Lagoa Rodrigo de Freitas. Durante seis meses foram realizadas quatro transecções (duas de manhã e duas à tarde). Quando as aves foram avistadas forrageando, foram registradas a profundidade da água e o tipo de presa capturada. Não foi encontrada relação estatisticamente significativa entre a eficiência de forrageamento para as duas espécies de aves. Entretanto, as espécies diferiram significativamente em relação à profundidade da água durante o forrageamento e também em relação aos itens alimentares capturados. Casmerodius albus capturou principalmente peixes, enquanto E. thula capturou principalmente invertebrados. Os resultados sugerem que diferenças na profundidade da água durante o forrageamento e nos ítens alimentares capturados permitem um uso diferencial dos recursos alimentares disponíveis para C. albus e E. thula na Lagoa Rodrigo de Freitas.

PALAVRAS-CHAVE. Profundidade de forrageamento, Casmerodius albus, Egretta thula, Lagoa Rodrigo de Freitas.

The coexistence of species with similar ecological requirements is supposed to rely on different habitat use (Heimsath et al., 1993) and microhabitat specialization (WHELAN 1989, 2001). On the feeding grounds, waterbirds distribution is determined by distribution of food resources (ZwARTs, 1974). The methods used by animals to search for food determine how and which kinds of prey they will encounter (Robinson \& Holmes, 1982), which reflects different foraging tactics used by species.

Some authors that have been studying the habitats used by waterbirds (e.g. Vides-Almonacid, 1990; Heimsath et al., 1993), including water depth selections (e.g. Willard, 1977, Ntiamoa-Baidu et al., 1998), observed differences in microhabitats utilization by different species (e.g. Heimsath et al., 1993). The foraging substrates and depth may vary among different species in the same environment. For example, each heron species (Ardeidae), which use aquatic environments to forage, occupy different substrates and depths to catch their preys (NTIAMOA-BAIDU et al., 1998). Herons and also egrets have long bills and stalk submerged prey while wading in shallow water (KATZIR et al., 1999), capturing their prey by a direct head movement (HANCOCK \& KUSHLAN, 1984; LOTEM et al., 1991).
Both Casmerodius albus (Linnaeus, 1758) and Egretta thula (Molina, 1782) (Ardeidae) occur throughout Brazil, in lakes, rivers and swamps (SicK, 1997), and generally feed on fishes in aquatic habitats. These two species differ in body size and foraging activities (KATZIR et al., 1999). These differences can reflect different ecological characteristics, such as prey selection and habitat use.

The aim of this study was to evaluate the water depth selection during foraging, efficiency in prey capture, and food items captured by C. albus and E. thula.

\section{MATERIAL AND METHODS}

The study was carried out at the margins of the Lagoa Rodrigo de Freitas, Rio de Janeiro State, Brazil (22 $57^{\prime} 02$ 'S $43^{\circ} 11^{\prime} 09^{\prime}$ 'W). This lagoon, which belongs to a chain of 11 large coastal lagoons, is disconnected from the sea by a sandy strand, and sea water enters the lagoon by a channel (Alves \& Pereira, 1998). It has an approximate surface of 233 ha and a water volume of $6,990,000 \mathrm{~m}^{3}$ with a maximum depth of $4.3 \mathrm{~m}$ (BRITO \& Lemos, 1982). The lagoon has an irregular shape with a perimeter of approximately $7.2 \mathrm{~km}$. The average rainfall in Rio de Janeiro city for the 30-years-period (1961-1990) 
was $1,172.9 \mathrm{~mm}$, whereas the average temperature during this period was $23.7^{\circ} \mathrm{C}\left(\max .=27.2^{\circ} \mathrm{C}\right.$ and $\left.\min =21.0^{\circ} \mathrm{C}\right)$ (Ministério da Agricultura e Reforma Agrária, 1992). This coastal lagoon and nearby lawns are used for leisure purposes, and are surrounded by buildings and streets with intense traffic (Alves \& PEREIRA, 1998).

The study was conducted from April to September 2003. The lagoon was divided into six imaginary sections, each one with an approximate extent of 1,200 $\mathrm{m}$ at the margins, including the correspondent water section. During each month we made four transects (one each week), being two in the morning (07:00 to 11:00 h), and two in the afternoon (14:00 to 18:00 h). Transects were conducted on the lagoon perimeter, beginning in a different section each week. The observations were carried out in days with similar weather conditions (sunny to cloudy days), avoiding rainy days. When the birds were seen foraging, they were observed for no more than 15 min to collect the following data: water depth, efficiency in prey capture, and food items. The water depth was estimated from the exposed vertical leg length. These measures were converted to water depth using measures of specimens from Museu Nacional do Rio de Janeiro.

Material examined. Casmerodius albus (6): BRAZIL, 01.III.1940, (MNRJ 2761); 01.III.1940, (MNRJ 2771); 01.III.1940 (MNRJ 2758); Goiás: Lagoa Grande, 18.II.1940, (MNRJ 6436); Minas Gerais: B. Paraopeba, 10.I.1934, C. Prej col. (MNRJ 6501); 01.III.1940, R. Frimmer col. (MNRJ 2776). Egretta thula (10): BRAZIL, 01.III.1940, (MNRJ 2775); 28.II.1940, (MNRJ 6491); 02.III.1940, (MNRJ 6492); 28.II.1940, (MNRJ 6494); Distrito Federal: 13.VIII.1941, L. C. Ferreira col. (MNRJ 23563); 29.I.1942, P. M. Britto col. (MNRJ 23629); Goiás: Rio Manoel Alves, 28.II.1946, R. Frimmer col. (MNRJ 6495); Lagoa Grande, 28.II.1946, R. Frimmer col. (MNRJ 6496); 02.III.1940, (MNRJ 7288); Rio de Janeiro: Mambucaba, 02.III.1940, (MNRJ 7587)

The mean leg length \pm standard error from the museum species were $25.2 \pm 3.4 \mathrm{~cm}$ (range $20.0-30.0 \mathrm{~cm}$ ), and $14.9 \pm 0.5 \mathrm{~cm}$ (range $14.3-15.5 \mathrm{~cm}$ ) for $C$. albus and $E$. thula, respectively. The foraging efficiency was quantified by the rate number of prey captured/number of attacks (PC/NA). The food items captured by C. albus and $E$. thula were registered and grouped in two categories: fishes and invertebrates.

The relationship between foraging efficiency and water depth selection used during foraging was tested by linear regression. Differences between foraging efficiencies were tested using $\mathrm{Z}$ - test for proportions. Differences between the water depth means for foraging for the two species were tested using Mann-Whitney test, since data were not normally distributed, as shown by the kurtosis and skewness of the data distribution (ZAR, 1999, Systat). The results are presented by arithmetic mean \pm standard error.

\section{RESULTSAND DISCUSSION}

Casmerodius albus and E. thula were frequently seen foraging on the margins of the lagoon, and significantly differed in relation to mean water depth for foraging (Mann-Whitney, U'=943, p <0.001, $\mathrm{N}=68$, df = 1) (fig. 1). The mean water depth used by $C$. albus during foraging was $15.5 \pm 8.5 \mathrm{~cm}(\mathrm{~N}=37)$, and the depth varied from 0 to $25 \mathrm{~cm}$, being the most frequent depth $25 \mathrm{~cm}$ (21.9\%). Egretta thula used a mean water depth of $5.6 \pm$ $4.6 \mathrm{~cm}(\mathrm{~N}=31)$, and the depth varied from 0 to $15 \mathrm{~cm}$, being the most frequent depth $0 \mathrm{~cm}(37.0 \%)$. These results suggest that $E$. thula uses mainly the portion near the edge of the lagoon while foraging, compared with Casmerodius albus, probably due to the fact that $E$. thula is smaller and uses a smaller range of depths than C. albus. This indicates a difference in the water depth use between both species during foraging. CUSTER \& OsBorn (1978) found that the water depth used for foraging by wading birds was dependent of the leg length. Besides, in the present study $C$. albus used a water depth range of $0-25 \mathrm{~cm}$ (the larger value corresponding to the bird's entire leg length) when capturing their prey, while in other studies, such as that of NTIAMOA-BAIDU et al. (1998), the amplitude varied from 2 to $15 \mathrm{~cm}$, suggesting that $C$. albus uses a wider range of water depths when foraging at Lagoa Rodrigo de Freitas.

The foraging efficiency did not differ significantly between $C$. albus and $E$. thula $(\mathrm{Z}=-0.997, \mathrm{p}=0.16)$, being 0.52 for $C$. albus $(\mathrm{N}=37)$ and 0.64 for $E$. thula $(\mathrm{N}=$ 31). This can be related to the similar foraging methods used by heron species (NTIAMOA-BAIDU et al., 1998), and the similar habitat used by both species (WILLARD, 1977 and RAMO \& Busto, 1993).

There is no significant relationship between the mean water depth and the foraging efficiency neither for C. albus $\left(\mathrm{F}_{1-35}=2.9 ; \mathrm{p}=0.097\right)$ nor for E. thula $\left(\mathrm{F}_{1-29}=\right.$ $0.39 ; \mathrm{p}=0.54)$. Egretta thula and C. albus presented similar catch efficiency. However, these species differed as to the depth used when foraging. This suggests that $C$. albus and E. thula may be using the food resources available in the lagoon in different ways. Indeed, the food items recorded for the two species were different. Casmerodius albus $(\mathrm{N}=72)$ captured mainly fishes

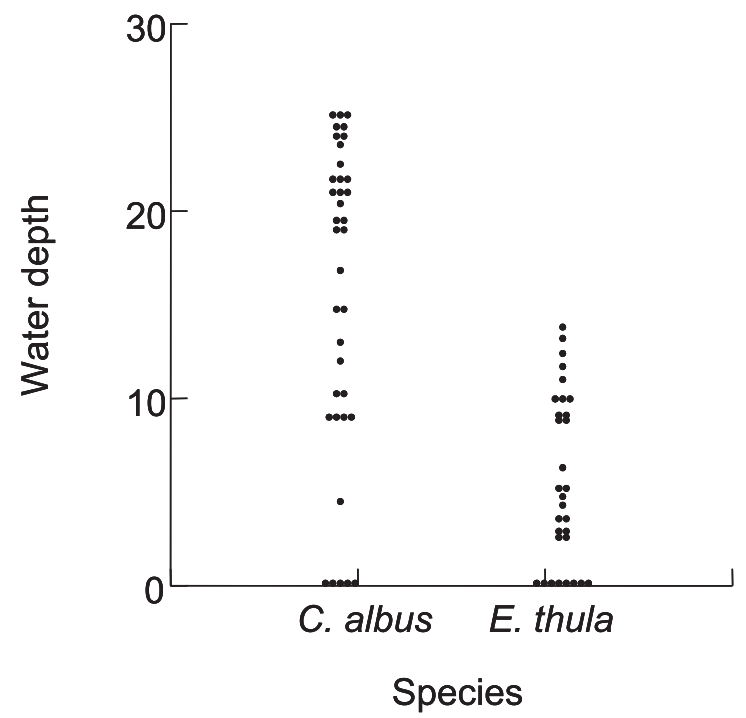

Fig. 1. Water mean depth used by individuals of Casmerodius albus $(\mathrm{N}=37)$ and Egretta thula $(\mathrm{N}=31)$ on the margins of Lagoa Rodrigo de Freitas, Rio de Janeiro State, Brazil. 
(75.0\%) while E. thula $(\mathrm{N}=170)$ captured more frequently invertebrates $(90.0 \%)$. Others studies (RAMO \& Busto, 1993; NitAMOA-BAIDU et al. 1998) using focal observations reported fishes as the main captured items for both egret species. However, besides fishes, Sick (1997) also reported small snakes and mice as prey items captured by $C$. albus. BAYNARD (1912) also found other items besides fishes for E. thula such as small suckers, grasshoppers, cut-worms and small lizards. This indicates that E. thula has a diverse diet.

The results of the present study suggest that the differences in the food items captured and the water depth used during foraging by both egrets studied permit a distinct use of the food resources available by $C$. albus and E. thula at the study area.

Acknowledgments. This study is part of the results of the "Ecology, Conservation and Management of Southeastern Brazilian Ecossystem Program" and of the Southeastern Brazilian Vertebrate Ecology Project (Laboratory of Vertebrate Ecology), both of the Departamento de Ecologia, Instituto de Biologia, Universidade do Estado do Rio de Janeiro. We also thank Davor Vrcibradic for his critical review, and also members of the Avian Ecology Group. This study was partially supported by a research grant from Conselho Nacional de Desenvolvimento Científico e Tecnológico (CNPq, process $\left.\mathrm{n}^{\circ} 302718 / 2003-6\right)$ to M. A. S. Alves, and also by graduate fellowships from CNPq to A. R. Lagos. A. B. Moreno received a Scientific Initial Grant from CNPq.

\section{REFERENCES}

Alves, M. A. S. \& Pereira, E. F. 1998. Richness, abundance and seasonality of birds species in a lagoon of an urban area (Lagoa Rodrigo de Freitas) of Rio de Janeiro, Ararajuba, 6(2):110-116.

Baynard, O. E. 1912. Food of herons and ibises. The Wilson Bulletin, 24(4):167-169.

Brito, I. M. \& Lemos, E. E. 1982. Evolução geológica e fauna da lagoa Rodrigo de Freitas, Rio de Janeiro. Anais da Academia Brasileira de Ciências, 54:143-164.

Custer, T. W. \& Osborn, R. G. 1978. Feeding habitat use by colonially breeding herons, egrets, and ibises in North Caroline. Auk, 95:733-743.

HanCoCK, J. \& Kushlan, J. 1984. The herons handbook. London, Croom Helm. 288p.

Heimsath, S. F.; Lopes de Casenova, J.; Cueto, V. R. \& Cittadino, E. A. 1993. Uso de habitat en Fulica armillata, Fulica leucoptera y Gallinula chloropus durante la primavera. Hornero, 13:286-289.

Katzir, G.; Strod, T.; Schechtman, E.; Hareli, S. \& Arad, Z. 1999. Cattle egrets are less able to cope with light refratection than are others herons. Animal Behaviour, 57:687-694.

Lotem, A.; Schechtman, E. \& Katzir, G. 1991. Capture of submerged prey by little egrets, Egretta garzetta: strike deph, strike angle and the problem of ligth refraction. Animal Behaviour, 42:341-346.

Ministério da Agricultura e Reforma Agrária. 1992. Normais Climatológicas 1961-1990. Brasília, SNI/DNM. 84p.

Ntiamoa-Baidu, Y.; Piersma, T.; Wiersma, P.; Poot, M.; Battley, P. \& Gordon, C. 1998. Water deph selection, daily feeding routines and diets of waterbirds in coastal lagoons in Ghana. Ibis, 140:89-103.

Ramo, C. \& Busto, B. 1993. Resource use by herons in Yucatan wetland during the breeding season. The Wilson Bulletin, 105(4):573-586.

Robinson, S. K. \& Holmes, R. T. 1982. Foraging behaviour of forest birds: the relationships among search tactics, diet, and habitat structurre. Ecology, 63(6):1918-1931.

SICK, H. 1997. Ornitologia brasileira, uma introdução. Rio de Janeiro, Editora Nova Fronteira. 912p.

Vides-Almonacid, R. 1990. Observaciones sobre la utilizacion del habitat y la diversidade de especies de aves en una laguna de la puna Argentina. Hornero, 13:117-128.

Whelan, C. J. 1989. Avian foliage structure preferences for foraging and the effect of prey biomass. Animal Behaviour, 38: $839-846$.

Whelan, C. J. 2001. Foliage structure influences foraging of insectivorous forest birds: an experimental study. Ecology, 82(1):219-231.

WiLlard, D. E. 1977. The feeding ecology and behaviour of five species of herons in Southeastern New Jersey. Condor, 79:462-470.

ZAR, J. H. 1999. Biostatistical analysis. Upper Saddle River, Prentice Hall. 663p.

Zwarts, L. 1974. Vogels van het brake getij-gebied, ecologische onderzoekingen op de Ventjagersplaten. Amsterdam, Jeugbond-suitgeverij. 212p.

Recebido em setembro de 2004. Aceito em março de 2005. ISSN 0073-4721

Artigo disponível em: www.scielo.br/isz 